\title{
The optical and electron microscopic determination of pulmonary asbestos fibre concentration and its relation to the human pathological reaction
}

\author{
T. ASHCROFT AND A. G. HEPPLESTON ${ }^{1}$ \\ From the Department of Pathology, University of Newcastle upon Tyne
}

SYNOPSIS The quantitative extraction of asbestos fibres from asbestotic lung by alkali digestion has $\stackrel{\infty}{\omega}$ been refined by maceration of the tissue without prior drying, the minimum use of centrifugation. N and the adoption of phase contrast microscopy. Preliminary experiments suggested that, using this

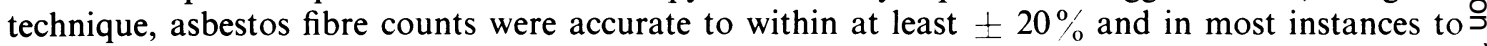
within $\pm 10 \%$.

The method was used to assess asbestos concentrations in lung tissue showing various degrees and forms of fibrosis. The results, as determined by light microscopy, indicated that uncoated fibres $\stackrel{\rho}{\supset}$ generally outnumbered coated fibres. In mild and moderate asbestosis there was a progressive $\vec{\varphi}$ increase in concentration of asbestos fibres, both coated and uncoated, with increasing severity of $\omega$ fibrosis, whereas in severe asbestosis no correlation existed between the fibre concentration and the form or the extent of the pathological reaction. It is suggested that the severe fibrosis results from the supervention of non-specific inflammatory processes.

Asbestos fibre diameter distributions, gauged by electron microscopy, were fairly constant irrespective of the degree of fibrosis. Optically visible fibres constituted between 12 and $30 \%$ of the total, so $\propto$ that an optical count may be said to give an approximate indication of the total asbestos concentration $\overrightarrow{0}$ and, so far as asbestosis is concerned, may well serve for comparative purposes. The relation between 3 asbestos and neoplasia will, however, require identification and quantitation of particular types of the mineral by microanalytical techniques.

In human and experimental silicosis, the severity of pulmonary fibrosis increases with the quantity of silica in the lung tissue (Nagelschmidt, 1960; Ross, King, Yoganathan, and Nagelschmidt, 1962). On the other hand, studies of human asbestosis have failed to demonstrate any clear correlation between the severity of fibrosis and the content of asbestos dust as determined in samples of lung tissue by ashing and acid extraction, with chemical estimation of silica (Beattie and Knox, 1961 : Nagelschmidt, 1965). This discrepancy prompted our enquiry into asbestos fibre concentrations in the lungs of asbestos-exposed individuals who did not show pulmonary fibrosis histologically or who had developed mild, moderate, or severe asbestosis. Furthermore, in individual examples of severe asbestosis, a comparison was made of the fibre contents from areas of lung showing Received for publication 10 January 1973.

${ }^{1}$ Reprint requests: Professor A. G. Heppleston, Department of Pathology, Royal Victoria Infirmary, Newcastle upon Tyne, NE1 4LP. different macroscopic forms of fibrosis. Light microscopy was employed to enumerate asbestos fibres but fibre diameter distributions were assessed by electron microscopy.

\section{Experimental}

METHODS

\section{Light microscopy}

Asbestos concentration was determined by macerating samples of lung tissue with concentrated potassium hydroxide $(\mathrm{KOH})$, counting coated and uncoated $\mathbb{\Phi}$ asbestos fibres in the resuspended residue, and ex- + pressing the result as number of fibres per gram of $\frac{}{T}$ dry tissue. The piece of lung tissue, measuring about $\frac{}{\mathrm{D}}$ $2 \times 1 \times 0.5 \mathrm{~cm}$, avoided major bronchi or pulmonary $\stackrel{\rho}{\longrightarrow}$ vessels and showed uniform pathological features; $\stackrel{\mathbb{Q}}{\varrho}$ it was divided into two approximately equal parts which were blotted dry and weighed. One half was 
dried overnight at 55 to $60^{\circ} \mathrm{C}$ and reweighed. The reduction in weight due to drying allowed the equivalent dry weight of the second half to be gauged. Without drying, the second portion was then macerated by immersion in about $6 \mathrm{ml}$ of $40 \%$ $\mathrm{KOH}$ in a clean $10 \mathrm{ml}$ conical centrifuge tube, which was kept in a bath of boiling water for 20 minutes. The volume was made up to $10 \mathrm{ml}$ with distilled water and the whole mixed by pipette in order to disperse floating black particles. Following centrifugation at $1700 \mathrm{~g}$ for 30 minutes, the supernatant was aspirated, leaving 0.5 to $1 \mathrm{ml}$ of fluid above the deposit. The sediment was resuspended in such a volume of distilled water as to yield an average concentration of 1 or 2 asbestos fibres, coated or uncoated, per small square of a Fuchs-Rosenthal counting chamber. Concentrations much in excess of this render counting inaccurate. If dilution to a volume over $10 \mathrm{ml}$ was necessary, an aliquot was taken from the well agitated suspension and further diluted in a second tube. This process sometimes had to be repeated. The dilution used was noted for the final calculation.

Having settled in the chamber for 30 minutes, coated and uncoated asbestos fibres were counted separately under phase-contrast illumination using a $\times 40$ objective. Initially a third category was recognized, comprising fibres for the most part uncoated but bearing small, irregular, eccentric accretions. Since the latter almost certainly represented fragments of tissue debris, this category was abandoned and such fibres were recorded as uncoated. At least 100 fibres were counted for each specimen, the chamber being filled several times if the tissue was poor in fibres. When fibres were numerous, between 200 and 500 were usually counted.

\section{Electron microscopy}

In certain cases a further sample of lung tissue was macerated as before and, having been centrifuged once at $1700 \mathrm{~g}$ for 30 minutes to remove the bulk of the $\mathrm{KOH}$, the fibre suspension was dialysed against frequent changes of distilled water through a Visking cellulose membrane until free of alkali. At this stage the dissolved organic material formed a flocculent precipitate. After centrifugation at $1700 \mathrm{~g}$ for 30 minutes the supernatant was discarded and the deposit ashed in a platinum crucible at $500^{\circ} \mathrm{C}$ for two hours. The residue was taken up into $10 \mathrm{ml}$ distilled water, recentrifuged at $1700 \mathrm{~g}$ for 30 minutes and, having removed the supernatant, resuspended in approximately $0.5 \mathrm{ml}$ of distilled water. A small drop of this suspension was allowed to dry on a formvar-coated grid and was then examined at 2000 $x$ magnification in a Siemens Elmiskop I electron microscope. Randomly selected fields were photo- graphed, and fibre diameters were measured on the prints at a final magnification of $5000 \times$, using a micrometer and viewing magnifier. The diameter recorded for coated fibres was that of the portions of bare fibre exposed at the ends or between segments of coating. Over 200 fibres, coated and uncoated, were measured in each case.

\section{COMMENT}

$\mathrm{KOH}$ maceration was used for asbestos quantitation by Gold (1968), but several aspects of the techniques developed here require emphasis.

\section{Use of phase-contrast microscopy}

In order to visualize the finer uncoated fibres the use of phase-contrast microscopy is essential. Figures 1 and 2 show how easily such fibres are overlooked when conventional illumination is employed.

\begin{tabular}{lllll}
\hline \multirow{2}{*}{ Count } & \multicolumn{2}{l}{ Number of Fibres } & \multicolumn{2}{l}{$\begin{array}{l}\text { Proportion of } \\
\text { Uncoated Fibres (\%) }\end{array}$} \\
\cline { 2 - 4 } & Total & Uncoated & Coated & \\
\hline 1 & 268 & 205 & 63 & $76 \cdot 5$ \\
2 & 262 & 184 & 78 & $70 \cdot 2$ \\
3 & 279 & 205 & 74 & $73 \cdot 5$ \\
4 & 233 & 167 & 66 & $71 \cdot 7$ \\
5 & 286 & 208 & 78 & $72 \cdot 7$ \\
6 & 287 & 213 & 74 & $74 \cdot 2$ \\
7 & 263 & 191 & 72 & $72 \cdot 6$ \\
8 & 284 & 212 & 72 & $74 \cdot 6$ \\
9 & 281 & 214 & 67 & $76 \cdot 2$ \\
10 & 229 & 175 & 54 & $76 \cdot 4$ \\
Mean & 267 & 197 & 70 & 73.9 \\
Standard & $21 \cdot 2$ & $17 \cdot 0$ & $7 \cdot 4$ & $2 \cdot 1$ \\
deviation & & & & \\
Coefficient of & & & & \\
variation (\%) & \pm 7.9 & $\pm 8 \cdot 6$ & $\pm 10 \cdot 6$ & $\pm 2 \cdot 8$ \\
\hline
\end{tabular}

Table I Variation between repeated fibre counts from the same suspension

Variation in counts of asbestos

To estimate the variation in counts of asbestos, coated and uncoated fibres were enumerated in 10 consecutive chambers from a single suspension of macerated asbestotic lung tissue (table I). The counts of total fibres and uncoated fibres have mean values well over 100 and coefficients of variation below \pm $10 \%$, while the coated fibre counts average below 100 and have a coefficient of variation a little over $\pm 10 \%$. The ratio of uncoated to total fibres, based on the two least variable counts, also has a low coefficient of variation. Repeated enumeration of blood eosinophils randomly distributed in the Fuchs-Rosenthal chamber gave a coefficient of variation of approximately $\pm 10 \%$ provided at least 100 cells were counted (Dacie and Lewis, 1968). Our findings suggest that asbestos enumeration is also accurate to within $\pm 10 \%$ when 100 or more fibres are counted. 


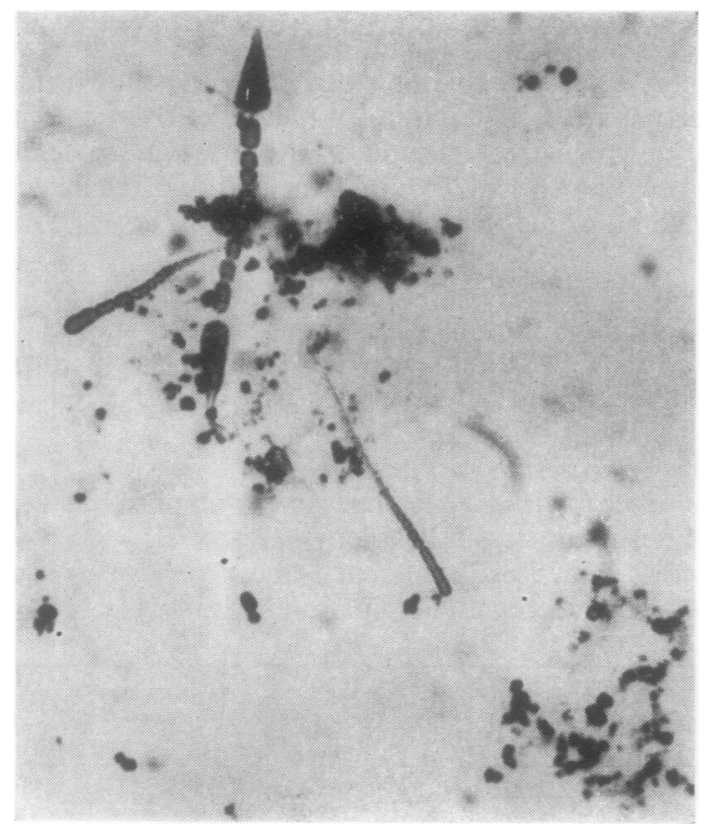

Fig. 1 Coated asbestos fibres after extraction from lung tissue and viewed by conventional illumination. No uncoated fibres can be recognized. $\times 400$.

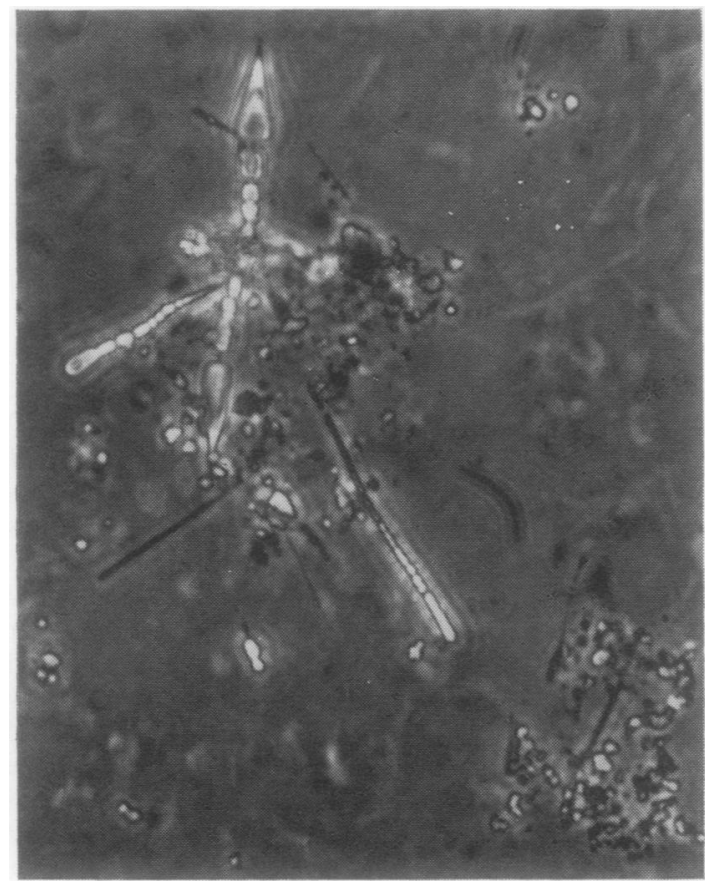

Fig. 2 The same field as in fig. 1 but viewed under phase-contrast illumination. Several uncoated asbestos fibres are seen as well as coated ones. $<400$.
Effect of repeated centrifugation

Repeated centrifugation of the macerated suspension $\overrightarrow{\vec{\rho}}$ leads to loss of uncoated fibres each time the super- $\frac{7}{0}$ natant is aspirated, as fig 3 shows in two typical 듬 suspensions. There is a sharp rise in the counts of $\frac{\overline{\bar{s}}}{\overline{0}}$ coated and uncoated fibres after the first centrifug- $\bar{\nabla}$ ation. The lower initial counts are probably explained by delayed settling of fibres in the counting chamber due to the greater viscosity of the concentrated $\vec{\circ}$ $\mathrm{KOH}$ in which they were suspended at that stage of $\overrightarrow{\vec{\omega}}$ the procedure. The coated fibre count thereafter $\stackrel{\sigma}{\omega}$ remains fairly constant through several successive $\frac{\bar{g}}{0}$ centrifugations, but the uncoated fibre count pro- $i$ gressively falls and eventually drops below that of the coated fibres. Further investigation showed that $i$ dust particles, including asbestos fibres, adhered to $\underset{\perp}{N}$ the tube walls after centrifugation. Much of the adherent dust was removed as the meniscus of the fluid passed over it during aspiration of the super- $z$ natant, and this dust was thus discarded. Dust adhesion appeared to be due to the presence on the $\stackrel{S}{\supset}$ tube walls of a sticky film, probably derived from $\vec{\omega}$ the organic material of the macerated lung.

\section{Drying tissue before maceration}

Drying the tissue before maceration leads to fracture of the longer coated and uncoated fibres. This effect is evident microscopically on comparing suspensions prepared from dried and wet portions of the same lung and it may exaggerate the fibre count. The numbers of fibres from wet and dried asbestotic lung tissue were compared in five cases, a sample of tissue from each being divided into two approximately equal-sized portions showing uniform pathological features. Both portions were weighed, one half being dried and the equivalent dry weight of the other calculated from the change in weight of the first. Both halves were then macerated and the counts are shown in table II. All five specimens show higher $\bigcirc$ coated fibre counts after drying, and in three specimens the uncoated fibre count is also increased.

\begin{tabular}{llllll}
\hline Specimen & $\begin{array}{l}\text { State when } \\
\text { Macerated }\end{array}$ & $\begin{array}{l}\text { Fibre Counts } \\
\text { (millions/g dried tissue) }\end{array}$ & $\begin{array}{l}\text { Proportion } \\
\text { of Uncoated } \\
\text { Fibres (\%) }\end{array}$ \\
\cline { 3 - 5 } & & Total & Uncoated & Coated & \\
\hline 1 & Moist & 187 & 154 & 33 & 82 \\
& Dry & 170 & 126 & 44 & 74 \\
3 & Moist & 261 & 234 & 27 & 90 \\
3 & Dry & 369 & 294 & 75 & 80 \\
4 & Moist & 27 & 19 & 8 & 70 \\
& Dry & 45 & 26 & 19 & 58 \\
5 & Moist & 16 & 12 & 4 & 75 \\
& Dry & 76 & 57 & 19 & 75 \\
& Moist & 269 & 232 & 37 & 86 \\
& Dry & 262 & 213 & 49 & 81 \\
\hline
\end{tabular}

Table II Fibre recovery from dried and wet tissue 


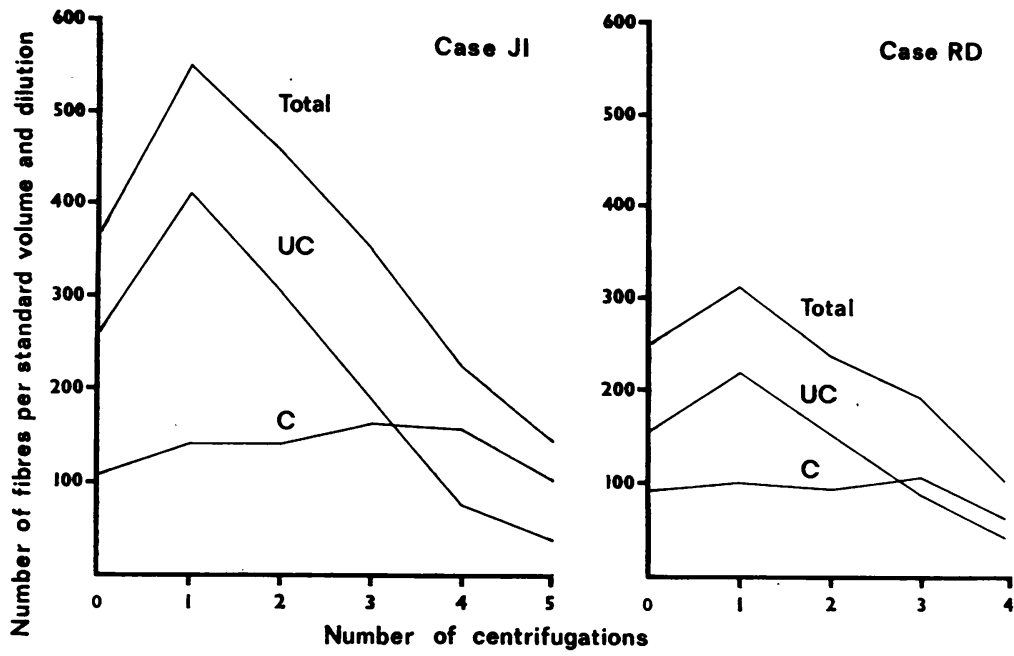

Fig. 3 Diagram to show fibre content (coated $(C)$, uncoated (UC) and total) of suspensions from two cases after repeated centrifugation. The fibre counts (ordinates) refer to a standard volume and dilution.

Use of equivalent dry weight of lung tissue

To estimate the error introduced by the use of an equivalent dry weight of lung tissue instead of the actual dry weight, 10 specimens showing various degrees of fibrosis, were each divided into two approximately equal pieces, which were blotted and weighed. Both pieces were dried at $60^{\circ} \mathrm{C}$ overnight and re-weighed, the change of weight in one part being used to calculate the equivalent dry weight of the second part, the estimated and measured dry weights of which were then compared (table III).

\begin{tabular}{|c|c|c|c|c|}
\hline Specimen & $\begin{array}{l}\text { Estimated } \\
\text { Dry Weight } \\
(\mathrm{g})\end{array}$ & $\begin{array}{l}\text { Measured } \\
\text { Dry Weight } \\
(g)\end{array}$ & Difference $(g)$ & $\begin{array}{l}\text { Difference as } \\
\text { Percentage } \\
\text { of Measured } \\
\text { Dry Weight }\end{array}$ \\
\hline $\begin{array}{l}\mathbf{b} \\
\mathbf{c} \\
\mathbf{d} \\
\mathbf{e} \\
\mathbf{f} \\
\mathbf{g} \\
\mathbf{h} \\
\mathbf{i} \\
\mathbf{j}\end{array}$ & $\begin{array}{l}0.2569 \\
0.1366 \\
0.1615 \\
0.2040 \\
0 \cdot 1752 \\
0 \cdot 1981 \\
0.0964 \\
0.2083 \\
0 \cdot 1893 \\
0 \cdot 1208\end{array}$ & $\begin{array}{l}0.2541 \\
0 \cdot 1190 \\
0 \cdot 1714 \\
0.1998 \\
0 \cdot 1667 \\
0.1669 \\
0.0820 \\
0 \cdot 2027 \\
0.1814 \\
0.1191\end{array}$ & $\begin{array}{r}+0.0028 \\
+0.0176 \\
-0.0099 \\
+0.0042 \\
+0.0085 \\
+0.0312 \\
+0.0144 \\
+0.0056 \\
+0.0079 \\
+0.0017\end{array}$ & $\begin{array}{l}+1.1 \\
+14.8 \\
-5.8 \\
+2.1 \\
+5.1 \\
+18.7 \\
+17.5 \\
+2.8 \\
+4.4 \\
+1.4\end{array}$ \\
\hline
\end{tabular}

Table III Comparison of estimated (ie, equivalent) and measured dry weights

+ signifies estimated weight greater than measured weight, and - signifies the reverse.

Differences between estimated and measured weights are mostly less than $6 \%$, though three specimens show differences up to $18.7 \%$. The estimated weight was greater than the measured weight in all but one specimen. The use of the equivalent dried weight may thus introduce an error into asbestos counts, but this error is unlikely to exceed $\pm 20 \%$ and in most counts will be considerably lower. However, the error is generally less than that which drying introduces into counts, especially of coated fibres (tables II and III).

\section{Electron microscope studies}

In the electron microscope studies attention was directed to fibre diameter rather than length because diameter, as the smaller dimension, determines whether or not the fibre will be resolved in an optical microscope.

Complete removal of the alkali before electron microscopy was necessary to avoid contamination or corrosion of the instrument. When, after dialysis, the suspension had ceased to giveanalkaline reaction to indicator paper, a flocculent precipitate formed, apparently consisting of the residual organic matter in the suspension. The precipitate, together with the mineral matter, was concentrated by further centrifugation, and the deposit was ashed to remove organic and carbonaceous material completely and produce a cleaner preparation on the grid. The purpose of the final centrifugation was again to protect the microscope by removing any remaining hydroxide from the ash. It is unlikely that uncoated fibres were lost during the last two centrifugations since the sticky film previously noted on the tube walls was no longer present.

\section{Application to the Asbestotic Reaction}

MILD AND MODERATE ASBESTOSIS

Lung tissue was analysed from 30 necropsy cases of 
diffuse malignant mesothelioma of the pleura or peritoneum. All showed coated asbestos fibres (asbestos bodies) in histological sections of lung and all but one individual had a history of definite or probable exposure to asbestos dust (table IV). An account of the mesotheliomas will be published separately (T.A.). Asbestosis was graded according to the classification of Beattie and Knox (1961) which resembles the U.I.C.C. classification (International Union Against Cancer, 1965). Thirteen cases showed no histological evidence of asbestosis (grade 0 ), 12 showed a slight or mild degree (grade + ), and five had moderately severe (grade ++ ) asbestosis. In the 25 pleural mesotheliomas, samples were taken from the unaffected or less affected lung whenever possible, but in 10 instances tissue was available only from the affected side. From the five peritoneal mesotheliomas the right lung provided the sample in three and the left lung in one, the site of origin of the sample being unrecorded in the fifth instance. One sample was examined in each case, the tissue customarily being taken from the base of the lower lobe.

SEVERE ASBESTOSIS

Lung tissue was available from five necropsies on severe asbestosis without malignant disease. The severity, extent, and form of fibrosis varied within a $\overrightarrow{\bar{N}}$ given lung, so permitting a comparison of fibre counts from areas appearing macroscopically normal or showing patchy fibrosis, solid fibrosis, or honeycomb change (Heppleston, 1956). The features of these different morphological forms are illustrated in figures 4,5 , and 6 . A total of 15 samples was analysed from the five cases.

\section{FIBRE RECOVERY}

\section{Mild and moderate asbestosis}

The recovery of asbestos fibres from lung tissue of associated with mesothelioma is shown in table $\mathrm{V}, \dot{\omega}$ where the cases are grouped according to the degree $\mathbb{N}$ of asbestosis. The fibre concentrations were extremely 음 variable, ranging from 154 thousand to 684 million fibres per gram dry lung. Uncoated fibres generally $\vec{z}$ outnumbered the coated ones, usually comprising 60 to $80 \%$ of the total count, but the proportion $\stackrel{3}{工}$ of uncoated fibres was rather more variable in the $\vec{\omega}$ absence of asbestosis.

Considered in relation to increasing severity of asbestosis, there is on the whole a progressive rise in fibre concentration, so far as these lesser grades

\begin{tabular}{|c|c|c|c|c|c|}
\hline Case Number & Age & Sex & Grade of Asbestosis & Duration of Asbestos Exposure (years) & Occupation \\
\hline 34 & 55 & $\mathbf{M}$ & 0 & Not known & Marine fitter \\
\hline 10 & 52 & $\mathbf{M}$ & $\mathbf{0}$ & 31 & Gas cooker renovator \\
\hline 8 & 57 & $\mathbf{M}$ & 0 & 12 & Shipyard labourer \\
\hline 14 & 67 & $\mathbf{F}$ & 0 & 5 & Asbestos factory worker \\
\hline 15 & 71 & $\mathbf{M}$ & $\mathbf{0}$ & 30 & Engine fitter \\
\hline 6 & 62 & $\mathbf{M}$ & 0 & $\begin{array}{l}17 \\
\text { (probable exposure) }\end{array}$ & Shipyard plater \\
\hline 20 & 63 & $\mathbf{M}$ & 0 & 6 months & Shipyard electrician \\
\hline 13 & 62 & $\mathbf{M}$ & 0 & 2 & Shipyard insulator \\
\hline 32 & 54 & $\mathbf{M}$ & $\mathbf{0}$ & 23 & Refrigeration engineer \\
\hline 18 & 55 & $\mathbf{M}$ & 0 & 25 & Shipyard insulator \\
\hline 27 & 62 & $\mathbf{M}$ & 0 & Not known & Not known \\
\hline 33 & 65 & $\mathbf{M}$ & 0 & 25 & Shipyard joiner \\
\hline 16 & 46 & $F$ & 0 & 1 & Asbestos factory worker \\
\hline 25 & 54 & $\mathbf{F}$ & + & 3 & Wife of asbestos worker \\
\hline 21 & 48 & $\mathbf{M}$ & + & 27 & Asbestos factory electrician \\
\hline 30 & 45 & $\mathbf{M}$ & + & 25 & Shipyard plater \\
\hline 41 & 73 & $\mathbf{M}$ & + & 40 & Dock labourer \\
\hline 23 & 52 & $\mathbf{M}$ & + & Few months & Carpenter \\
\hline 31 & 68 & $\mathbf{M}$ & $\div$ & 40 & Pipe lagger \\
\hline 26 & 66 & $\mathbf{M}$ & + & 24 & Boiler cleaner \\
\hline 17 & 62 & $\mathbf{M}$ & + & 47 & Shipyard electrician \\
\hline 7 & 42 & $\mathbf{F}$ & + & 4 & Asbestos factory worker \\
\hline 37 & 50 & $\mathbf{M}$ & + & 22 & Pipe lagger \\
\hline 9 & 47 & $\mathbf{M}$ & + & 30 & Pipe lagger \\
\hline 29 & 56 & $\mathbf{M}$ & $\div$ & 34 & Shipyard engineer \\
\hline 40 & 59 & $\mathbf{M}$ & $+i$ & 31 & Pipe lagger \\
\hline 24 & 44 & $\mathbf{M}$ & +1 & 25 & Shipyard plater \\
\hline 38 & 43 & $\mathbf{M}$ & ++ & 29 & Pipe lagger \\
\hline 28 & 58 & $\mathbf{M}$ & ++ & 37 & Pipe lagger \\
\hline 39 & 49 & $\mathbf{M}$ & $+t$ & 18 & Asbestos sprayer \\
\hline 42 & 64 & $\mathbf{M}$ & $+\cdots+$ & 38 & Pipe lagger \\
\hline 43 & 57 & $\mathbf{M}$ & $++t$ & 12 & Asbestos insulation packer \\
\hline 44 & 63 & $\mathbf{M}$ & +++ & 19 & Asbestos disintegrator \\
\hline 45 & 63 & $\mathbf{M}$ & $++\div$ & 11 & Asbestos factory worker \\
\hline 46 & 58 & $\mathbf{M}$ & $+t+$ & 2 & Asbestos factory worker \\
\hline
\end{tabular}




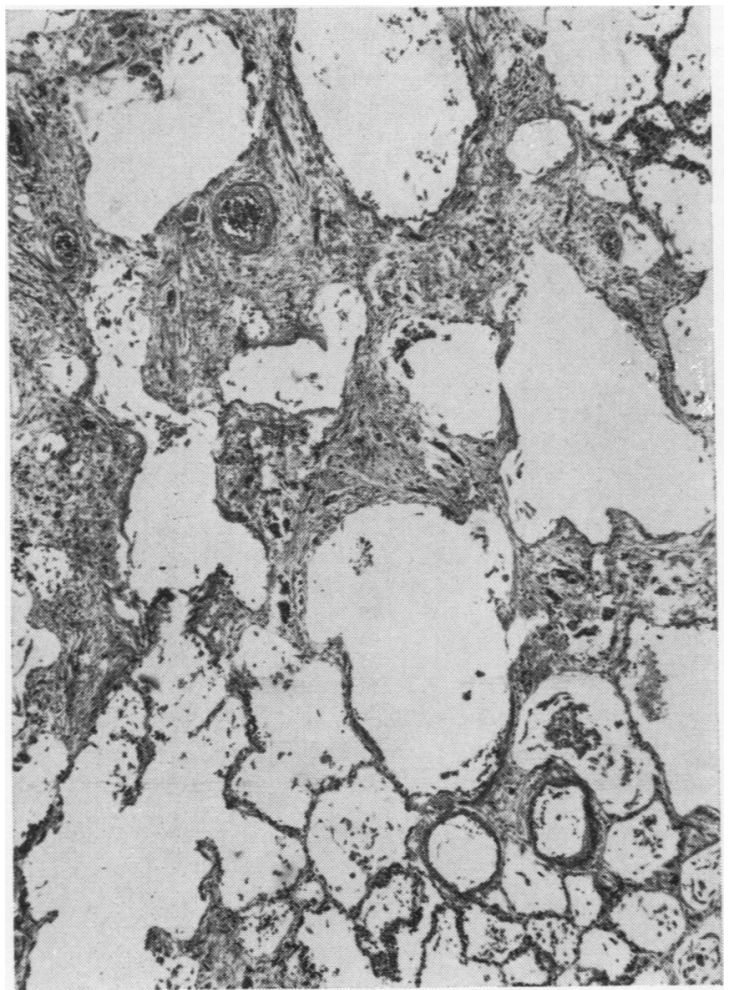

Fig. 4

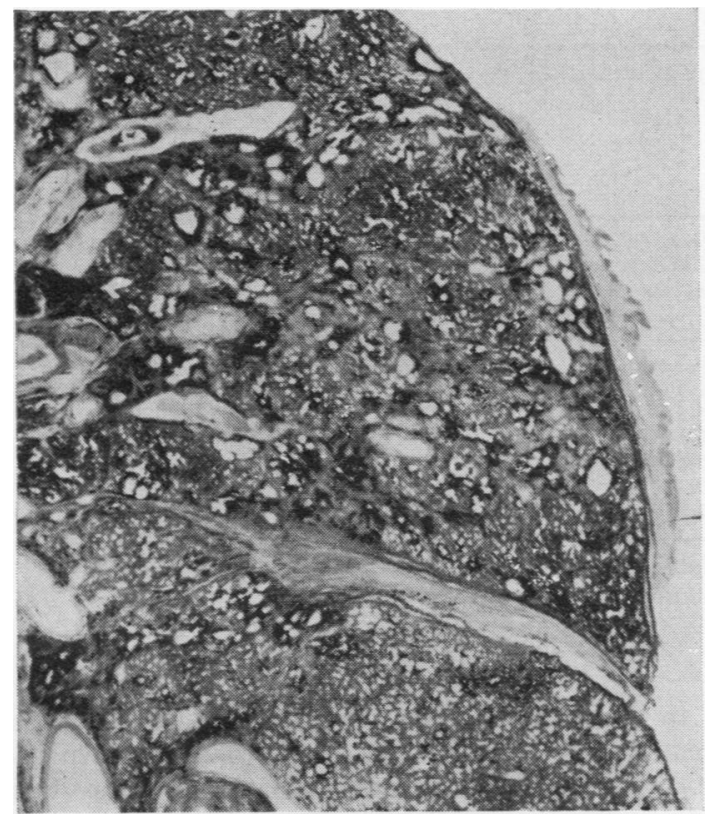

Fig. 6

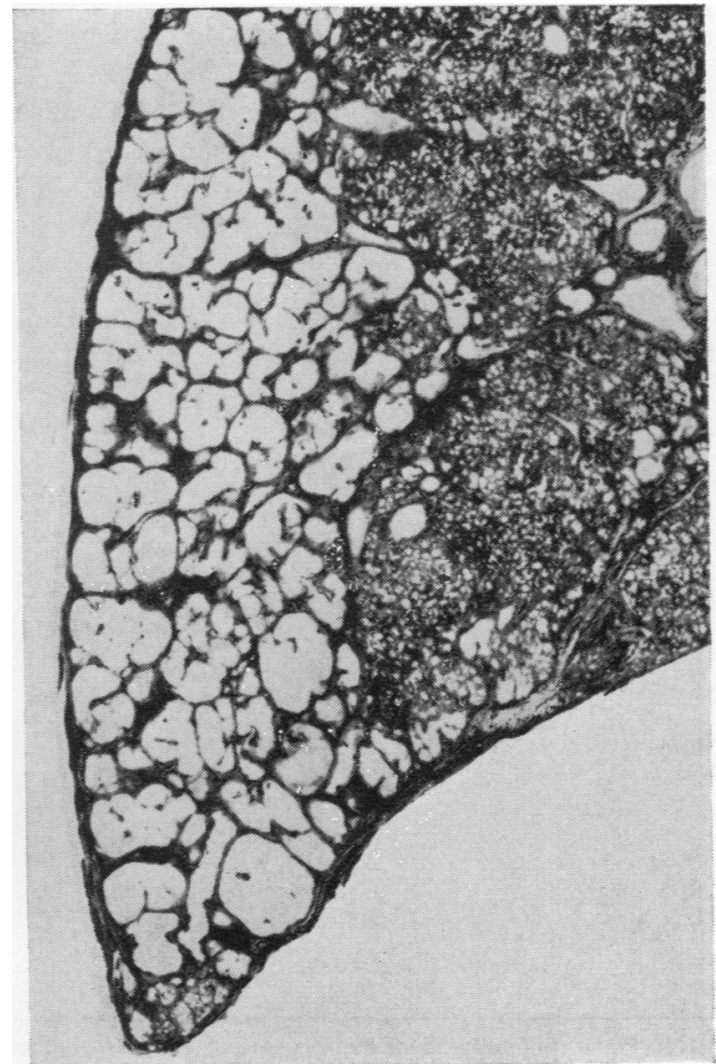

Fig. 5

Fig. 4 Focal distribution of fibrosis from a case of severe asbestosis. $\mathrm{HE}, \times 40$.

Fig. 5 Honeycomb (fibrocystic) change affecting the posterior aspect of the lower lobe in severe asbestosis. From a whole organ section, $\times 1$.

Fig. 6 Solid type of fibrosis extending from the hilum to the pleura. The lung also shows focal pigmentation. From a whole organ section. $\times 1$. 


\begin{tabular}{|c|c|c|c|c|c|c|c|}
\hline \multirow[t]{2}{*}{ Case Number } & \multirow{2}{*}{$\begin{array}{l}\text { Grade of } \\
\text { Asbestosis }\end{array}$} & \multicolumn{3}{|c|}{ Fibre Counts (millions/g dried tissue) } & \multirow{2}{*}{$\begin{array}{l}\text { Proportion } \\
\text { Uncoated } \\
\text { Fibres }(\%)\end{array}$} & \multirow{2}{*}{$\begin{array}{l}\text { Residence } \\
\text { Time (years) }\end{array}$} & \multirow{2}{*}{$\begin{array}{l}\text { Asbestos } \\
\text { Exposure (years) }\end{array}$} \\
\hline & & Total & Uncoated & Coated & & & \\
\hline 34 & $\mathbf{0}$ & 0.154 & $0 \cdot 128$ & 0.026 & 83 & Unknown & $?$ \\
\hline 10 & $\mathbf{0}$ & $0 \cdot 166$ & $0 \cdot 104$ & 0.062 & 63 & 35 & 31 \\
\hline 8 & 0 & 0.434 & $0 \cdot 273$ & $0 \cdot 160$ & 63 & 30 & 12 \\
\hline 14 & 0 & 0.438 & 0.367 & 0.071 & 84 & 51 & 5 \\
\hline 15 & 0 & 0.494 & $0 \cdot 368$ & $0 \cdot 126$ & 75 & 30 & 30 \\
\hline 6 & 0 & 0.789 & 0.390 & 0.399 & 49 & 46 & 17 \\
\hline 20 & 0 & 0.892 & $0 \cdot 706$ & $0 \cdot 186$ & 79 & 30 & 0.5 \\
\hline 13 & 0 & $1 \cdot 710$ & 0.855 & 0.855 & 50 & 37 & 2 \\
\hline 32 & 0 & $2 \cdot 291$ & 1.718 & 0.573 & 75 & 23 & 23 \\
\hline 18 & $\mathbf{0}$ & 4.039 & $2 \cdot 187$ & $1 \cdot 852$ & 54 & 25 & 25 \\
\hline 27 & $\mathbf{0}$ & 8.018 & $2 \cdot 981$ & $5 \cdot 037$ & 37 & Unknown & $?$ \\
\hline 33 & 0 & $8 \cdot 189$ & $4 \cdot 136$ & 4.053 & 51 & 25 & 25 \\
\hline 16 & $\mathbf{0}$ & 20.686 & $16 \cdot 392$ & $4 \cdot 294$ & 79 & 33 & 1 \\
\hline Mean & (13 cases) & $3 \cdot 715$ & $2 \cdot 354$ & $1 \cdot 361$ & 65 & $33^{*}$ & $16^{*}$ \\
\hline SD & & $5 \cdot 8$ & $4 \cdot 4$ & $1 \cdot 8$ & $15 \cdot 4$ & $8 \cdot 8$ & $11 \cdot 96$ \\
\hline 25 & + & $1 \cdot 749$ & $1 \cdot 262$ & 0.487 & 72 & 33 & 3 \\
\hline 21 & + & 4.975 & $3 \cdot 223$ & $1 \cdot 752$ & 65 & 32 & 27 \\
\hline 30 & + & $6 \cdot 508$ & $3 \cdot 597$ & 2.911 & 55 & 25 & 25 \\
\hline 41 & + & 6.975 & $4 \cdot 780$ & $2 \cdot 195$ & 69 & 40 & 40 \\
\hline 23 & + & $7 \cdot 705$ & $6 \cdot 398$ & $1 \cdot 307$ & 83 & 28 & $?$ \\
\hline 31 & + & $12 \cdot 276$ & 8.941 & $3 \cdot 335$ & 73 & 43 & 40 \\
\hline 26 & + & $25 \cdot 747$ & 15.421 & $10 \cdot 326$ & 60 & 25 & 24 \\
\hline 17 & + & $43 \cdot 760$ & 31.036 & $12 \cdot 724$ & 71 & 47 & 47 \\
\hline 7 & + & $44 \cdot 746$ & $34 \cdot 310$ & 10.436 & 77 & 26 & 4 \\
\hline 37 & + & 53.865 & $40 \cdot 707$ & $13 \cdot 158$ & 76 & 22 & 22 \\
\hline 9 & + & $54 \cdot 228$ & $38 \cdot 680$ & $15 \cdot 548$ & 71 & 33 & 30 \\
\hline 29 & + & $64 \cdot 865$ & $46 \cdot 946$ & $17 \cdot 919$ & 72 & 42 & 34 \\
\hline Mean & (12 cases) & $27 \cdot 283$ & $19 \cdot 608$ & $7 \cdot 675$ & 70 & 33 & $27^{1}$ \\
\hline SD & & $23 \cdot 4$ & $17 \cdot 3$ & $6 \cdot 3$ & $7 \cdot 5$ & $8 \cdot 3$ & $13 \cdot 9$ \\
\hline 40 & ++ & $82 \cdot 839$ & 55.947 & $26 \cdot 892$ & 68 & 40 & 31 \\
\hline 24 & ++ & $101 \cdot 130$ & $68 \cdot 624$ & $32 \cdot 506$ & 68 & 31 & 25 \\
\hline 38 & ++ & $166 \cdot 296$ & 133.441 & $32 \cdot 855$ & 80 & 29 & 29 \\
\hline 28 & ++ & 337.009 & $266 \cdot 544$ & $70 \cdot 465$ & 79 & 41 & 37 \\
\hline 39 & $+t$ & $684 \cdot 314$ & $492 \cdot 538$ & $191 \cdot 776$ & 72 & 18 & 18 \\
\hline $\begin{array}{l}\text { Mean } \\
\text { SD }\end{array}$ & (5 cases) & $\begin{array}{l}274 \cdot 318 \\
250 \cdot 2\end{array}$ & $\begin{array}{l}203 \cdot 418 \\
181 \cdot 9\end{array}$ & $\begin{array}{l}70 \cdot 899 \\
69 \cdot 8\end{array}$ & $\begin{array}{l}73 \\
6 \cdot 0\end{array}$ & $\begin{array}{l}32 \\
9 \cdot 4\end{array}$ & $\begin{array}{l}28 \\
7 \cdot 1\end{array}$ \\
\hline
\end{tabular}

Table V Pulmonary asbestos fibre counts related to severity of asbestosis in mesothelioma cases

${ }^{1} 11$ cases

are concerned (table V). The mean counts of coated, uncoated, and total fibres show successive six to 10 -fold increases between the groups of cases with no $(0)$ asbestosis, mild $(+)$ asbestosis, and moderate $(++)$ asbestosis. The counts for coated, uncoated, and total fibres show a log-normal distribution within each grade of asbestosis and the grades were therefore compared by means of a $t$ test using the logarithms of the individual values. Although there is a wide scatter about the means and a considerable overlap in the ranges associated with the 0 and + grades of asbestosis, the differences between grades in the means for coated, uncoated, and total fibre counts are statistically significant, the $P$ values all lying between 0.005 and 0.001 . The mean proportion of uncoated fibres also shows a small progressive rise with increasing severity of fibrosis, but the differences between grades of asbestosis are not statistically significant.

\begin{tabular}{lccl}
\hline $\begin{array}{l}\text { Years between } \\
\text { Last Exposure } \\
\text { and Death }\end{array}$ & $\begin{array}{l}\text { No. of } \\
\text { Cases }\end{array}$ & $\begin{array}{l}\text { Mean Total Fibre Counts } \\
\text { (millionsig dry weight) }\end{array}$ & $\begin{array}{l}\text { Mean } \\
\text { Proportion } \\
\text { Uncoated } \\
\text { Fibres (\%) }\end{array}$ \\
\hline Less than 1 & 13 & 87 & 67 \\
$1-4$ & 3 & 125 & 71 \\
$5-9$ & 3 & 52 & 70 \\
$10-14$ & Nil & & 73 \\
$15-19$ & 2 & 4 & 63 \\
$20-29$ & 2 & 23 & 73 \\
30 and over & 5 & 5 & \\
\hline
\end{tabular}

Table VI Duration of survival after exposure in relation to fibre content

In table VI the proportion of uncoated fibres is related to the time elapsing from the last known exposure to asbestos and death, in cases where this information is available. There is no apparent difference in the mean proportion of uncoated fibres 
between cases with long and short postexposure survival times. The mean fibre counts were higher with shorter than with longer survivals because all the patients with moderate asbestosis and most of those with mild fibrosis died within nine years of the last exposure, whilst most of the patients devoid of asbestosis lived for $\mathbf{1 5}$ or more years after leaving the hazard. Moreover, no relationship was found between grade of asbestosis and either length of asbestos exposure or the period from first exposure to death, ie, the residence time (table V).

\section{Severe asbestosis}

The counts obtained in 15 samples of lung from the five cases of severe asbestosis are shown in table VII. The four types of area extracted in case 42 were macroscopically normal or showed focal fibrosis, solid fibrosis, or fibrocystic disease (honeycombing). In the left lung the highest fibre concentration was found in tissue of normal appearance, that in solid fibrosis being only slightly lower, but focal fibrosis contained least fibres. In the right lung the cystic sample contained more fibres than the non-fibrotic tissue which, however, contained fewer than nonfibrotic tissue on the left side. In case 43 macroscopically normal tissue contained many more fibres than finely cystic tissue and more than tissue that was partly fibrocystic and partly solid. The fibre content in case $\mathbf{4 5}$ was high and only a little greater in areas of solid fibrosis than in tissue of normal appearance. Cystic areas of case 46 contained more fibres than non-fibrotic tissue, whereas the reverse obtained in case 44 where the fibre content was much lower. In all samples naked fibres outnumbered coated ones, and though a little more evident with the higher counts of cases 45 and 46, the proportion of uncoated fibres did not vary greatly. The total fibre counts in cases 42,43 , and 44 lay mostly within the range associated with mild asbestosis in the mesothelioma cases, while the counts noted in cases 45 and 46 lay within the range for moderate asbestosis in the mesothelioma group. In severe asbestosis no correlation evidently exists between the fibre concentration or the proportion of uncoated fibres on the one hand and the form or the severity of the pathological reaction on the other.

\begin{tabular}{|c|c|c|c|c|c|c|}
\hline \multirow[t]{2}{*}{ Case No. } & \multicolumn{2}{|c|}{ Pathological Form of Disease } & \multicolumn{4}{|c|}{ Fibre Counts (millions/g dried lung) } \\
\hline & & & Total & Uncoated & Coated & Proportion Uncoated Fibres ( $\%$ ) \\
\hline \multirow[t]{2}{*}{42} & Left & $\begin{array}{l}\text { Nonfibrotic } \\
\text { Focal fibrosis } \\
\text { Solid fibrosis }\end{array}$ & $\begin{array}{r}31 \\
8 \\
28\end{array}$ & $\begin{array}{r}22 \\
6 \\
20\end{array}$ & $\begin{array}{l}9 \\
2 \\
8\end{array}$ & $\begin{array}{l}71 \\
75 \\
71\end{array}$ \\
\hline & Right & $\begin{array}{l}\text { Nonfibrotic } \\
\text { Cystic }\end{array}$ & $\begin{array}{l}18 \\
32\end{array}$ & $\begin{array}{l}13 \\
22\end{array}$ & $\begin{array}{r}5 \\
10\end{array}$ & $\begin{array}{l}72 \\
69\end{array}$ \\
\hline 43 & Left & $\begin{array}{l}\text { Nonfibrotic } \\
\text { Finely cystic } \\
\text { Cystic/solid }\end{array}$ & $\begin{array}{r}68 \\
7 \\
41\end{array}$ & $\begin{array}{r}46 \\
5 \\
30\end{array}$ & $\begin{array}{r}22 \\
2 \\
11\end{array}$ & $\begin{array}{l}68 \\
71 \\
73\end{array}$ \\
\hline 44 & Right & $\begin{array}{l}\text { Nonfibrotic } \\
\text { Cystic }\end{array}$ & $\begin{array}{l}43 \\
12\end{array}$ & $\begin{array}{l}27 \\
10\end{array}$ & $\begin{array}{r}16 \\
2\end{array}$ & $\begin{array}{l}63 \\
83\end{array}$ \\
\hline 45 & Right & $\begin{array}{l}\text { Nonfibrotic } \\
\text { Solid fibrosis }\end{array}$ & $\begin{array}{l}311 \\
353\end{array}$ & $\begin{array}{l}247 \\
304\end{array}$ & $\begin{array}{l}64 \\
49\end{array}$ & $\begin{array}{l}79 \\
86\end{array}$ \\
\hline 46 & Left & $\begin{array}{l}\text { Nonfibrotic } \\
\text { Cystic } \\
\text { Cystic }\end{array}$ & $\begin{array}{l}350 \\
473 \\
517\end{array}$ & $\begin{array}{l}289 \\
410 \\
445\end{array}$ & $\begin{array}{l}61 \\
63 \\
72\end{array}$ & $\begin{array}{l}83 \\
87 \\
86\end{array}$ \\
\hline
\end{tabular}

Table VII Fibre counts in relation to morphological form in severe asbestosis

\begin{tabular}{|c|c|c|c|c|c|c|}
\hline \multirow[t]{2}{*}{ Fibre Diameter $(\mu m)$} & \multicolumn{6}{|c|}{ Distribution of Fibres $(\%)$ According to Severity of Asbestosis } \\
\hline & $\begin{array}{l}\text { Mild } \\
\text { (Case 7) }\end{array}$ & $\begin{array}{l}\text { Mild } \\
\text { (Case 9) }\end{array}$ & $\begin{array}{l}\text { Moderate } \\
\text { (Case 24) }\end{array}$ & $\begin{array}{l}\text { Moderate } \\
\text { (Case 38) }\end{array}$ & $\begin{array}{l}\text { Severe } \\
\text { (Case 44) }\end{array}$ & $\begin{array}{l}\text { Severe } \\
\text { (Case 45) }\end{array}$ \\
\hline $\begin{array}{l}<0 \cdot 1 \\
0 \cdot 1-0 \cdot 19 \\
0 \cdot 2-0 \cdot 29 \\
0 \cdot 3-0 \cdot 39 \\
0 \cdot 4-0.49 \\
0 \cdot 5-0 \cdot 59 \\
0 \cdot 6-0 \cdot 69 \\
0 \cdot 7-0 \cdot 79 \\
0 \cdot 8 \text { and over }\end{array}$ & $\left.\begin{array}{l}21 \\
33 \\
17 \\
10 \\
6 \\
4 \\
1 \\
3 \\
5\end{array}\right\} 19$ & $\left.\begin{array}{c}24 \\
31 \\
17 \\
10 \\
7 \\
3 \\
2 \\
2 \\
4\end{array}\right\} 18$ & $\left.\begin{array}{c}14 \\
28 \\
14 \\
15 \\
6 \\
7 \\
4 \\
3 \\
9\end{array}\right\} 29$ & $\left.\begin{array}{c}19 \\
42 \\
18 \\
9 \\
4 \\
3 \\
2 \\
2 \\
1\end{array}\right\} 12$ & $\left.\begin{array}{c}28 \\
31 \\
18 \\
9 \\
5 \\
3 \\
3 \\
2 \\
1\end{array}\right\} 14$ & $\left.\begin{array}{c}14 \\
29 \\
21 \\
16 \\
6 \\
3 \\
3 \\
1 \\
7\end{array}\right\} 20$ \\
\hline
\end{tabular}

Table VIII Fibre diameter distribution determined by electron microscopy in relation to the severity of asbestosis 


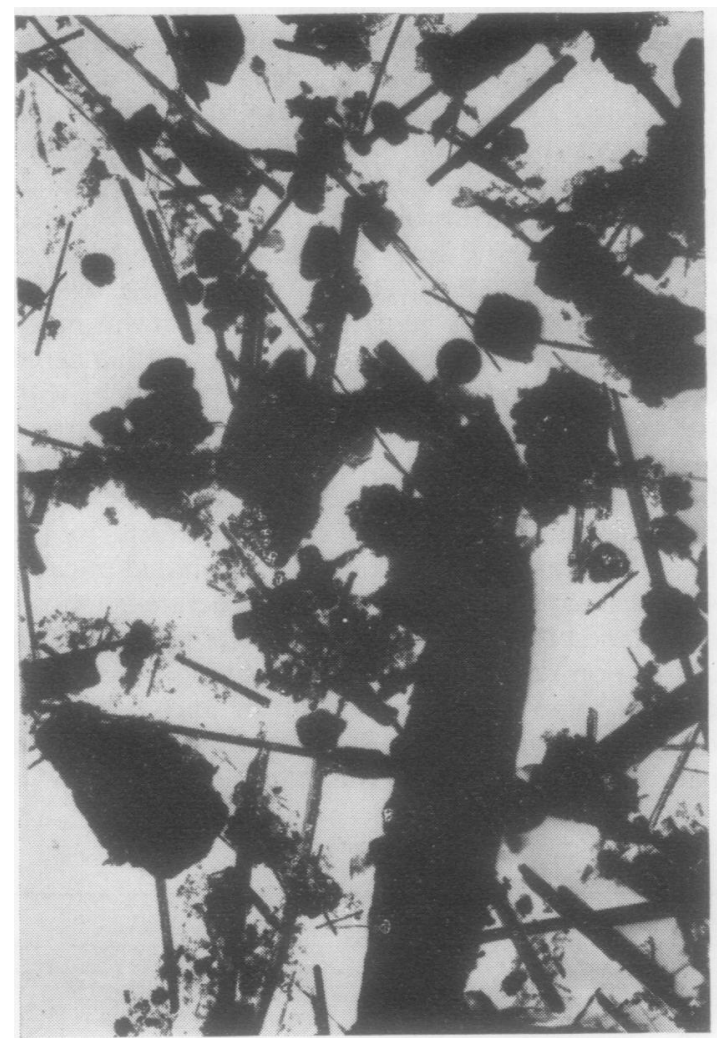

Fig. 7

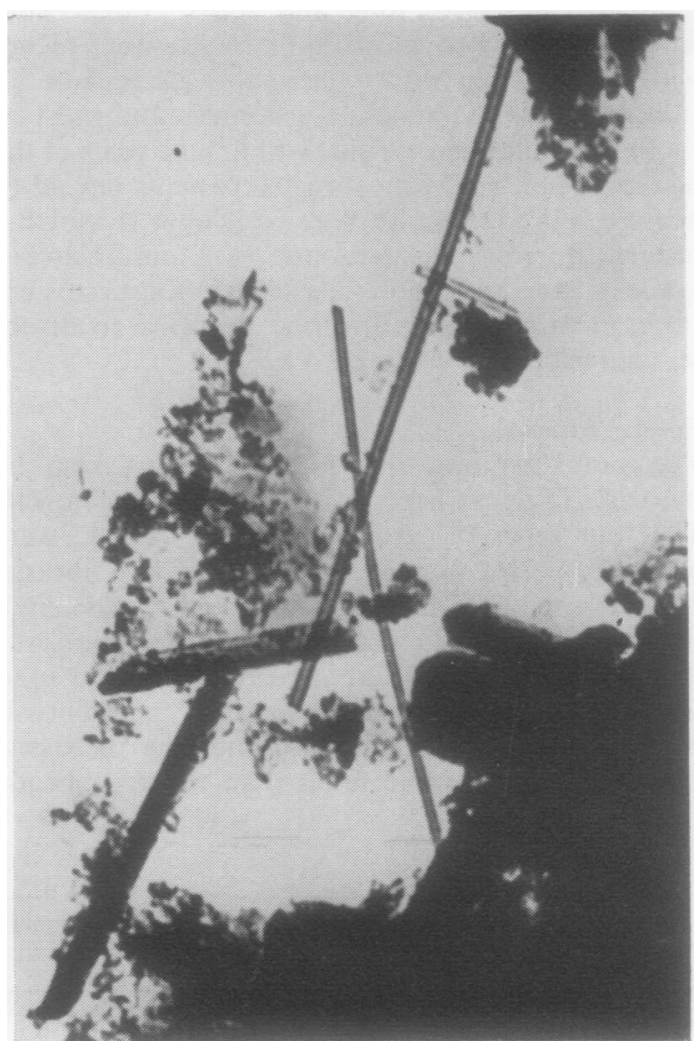

Fig. 8

Fig. 7 Electron micrograph of fibres recovered from a case of severe asbestosis. Coated and uncoated fibres aïe present and appear to be exclusively amphibole. $\times 3000$.

Fig. 8 Electron micrograph of another suspension which includes fibres whose structure suggests chrysotile. The suspension as a whole contained a majority of amphibole type material. $\times 25000$.

\section{Fibre diameter distribution}

The distributions in six cases, two from each grade of asbestosis, are given in table VIII. In each case fibres in the range 0.1 to $0.19 \mu \mathrm{m}$ were most numerous. Less than a third, and usually less than a fifth, of the fibres were optically visible, ie, had a diameter of $0.4 \mu \mathrm{m}$ or over. It must be stressed that in this respect there was no difference between the grades of asbestosis. Diffraction studies were not undertaken, but the vast majority of fibres had the appearance of amphibole asbestos and only occasional chrysotile fibres were identified by a tubular structure at high magnification (figs 7 and 8).

\section{Discussion}

The high proportion of uncoated fibres found in the majority of our lung analyses by light microscopy was not anticipated and contrasts with the histologicalo appearances in asbestotic lung tissue. The importance of phase-contrast microscopy in visualizing uncoated fibres must again be emphasized. Persistence of uncoated fibres many years after the last exposure to $\mathrm{Gr}$ asbestos, in proportions similar to those found in $N$ men exposed until shortly before death, suggests $\underset{\omega}{N}$ that no preferential dissolution of either coated or 0 uncoated fibres occurs with time (table VI). These findings are thus not entirely in accord with the sugges- $\frac{\bar{D}}{\Phi}$ tion of Beattie (1961) that asbestos bodies disinte- $\stackrel{0}{?}$ grate after 10 to 15 years. Uncoated fibres are present 0 in abundance at all stages of the disease, a finding which is in keeping with their presumed role as the $\mathbb{\mathbb { D }}$ fibrogenic agent in asbestosis. It is clearly insufficient $\mathbb{D}$ to restrict attention to coated fibres as did Smith and Naylor (1972), who were concerned only with routine necropsy material. 
The present study appears to be the first to present fibre counts from asbestotic lungs showing a full spectrum of pathological features. There was no suggestion of any qualitative difference in the type of tissue reaction to inhaled asbestos fibres between cases of mesothelioma and of asbestosis without mesothelioma. The proportions of uncoated fibres recovered from mildly or moderately fibrotic lungs and from severe asbestosis were closely similar.

Presenting fibre counts as numbers per gram of dried lung tissue may introduce an error, to which Collins and Dible (1935) drew attention when determining the silica content of the lung. For the same number of fibres, increasing density of the lung tissue, whether due to fibrosis or to pneumonia, will lead to a decrease of fibres per unit weight. In this study, however, no other method was available. Pneumonic lung was avoided as far as possible when taking samples for analysis, but differences in tissue density probably contribute to the wide scatter of counts about the means (table V). Furthermore the grades of asbestosis represent portions of a continuum rather than clear-cut stages, so that a range of values would be expected. The individual errors due to varying tissue density will, however, be minimized when counts from a number of cases are averaged, as in the mesothelioma series. Thus individual results must be regarded as an approximation, but the differences between the means of groups with $0,+$, and ++ disease may be accepted as reliable. The effect of varying tissue density could still be held responsible for some of the variation in tibre counts between different areas of lung in the five cases of severe $(t++)$ asbestosis. However, table VII shows that fibrotic or fibrocystic areas may contain fewer, more, or similar numbers of fibres than non-fibrotic areas of the same lung when expressed on a unit weight basis. The differing concentrations can be interpreted as indicating that the diseased areas originally contained fibres in equal, greater, or lesser numbers than unaffected lung. It is therefore reasonable to conclude that fibre concentration in particular areas bears no consistent relationship to the degree or form of the fibrosis in advanced disease. The concentrations of fibres, coated and uncoated, found in the severely asbestotic lungs from the five cases (table VII) correspond to the ranges associated with mild or with moderate asbestosis in the cases of mesothelioma. It is apparent that progression of disease from 'no asbestosis' through 'mild asbestosis' to 'moderate asbestosis' is associated with a progressive increase in the fibre content of the lung tissues (table V), but further progression to 'severe asbestosis' is not associated with any additional increase in asbestos concentration (table VII).
These considerations, together with the irregular distribution of the morphological changes within individual lungs, suggest that, while mild or moderate fibrosis is directly related to the amount of asbestos dust retained, the changes of severe asbestosis show no such relationship but are due to the intervention of secondary pathological processes. Neither the cystic nor the solid forms exhibited whorled, hyaline fibrosis, the histological features being distinct from massive silicotic fibrosis. There was no pathological evidence of tuberculosis in any of the cases considered here and Smither (1965) pointed out that the incidence of tuberculosis in asbestosis is now much lower than in former years. The close resemblance, amounting indeed to identity, between fibrocystic asbestosis and the non-specific form of honeycomb lung may nevertheless mean that the presence of asbestos or the reaction to it predisposes to non-specific inflammatory states which may leave residual fibrosis or honeycombing in the manner described by Heppleston $(1956,1969)$. This interpretation is consistent with the clinical view that non-specific pulmonary infection accelerates the progression of asbestosis (Elder, 1967). Inadequate therapy in pulmonary infections of bronchopneumonic distribution may result in healing by fibrosis rather than resolution, with fibrocystic disease as the ultimate state. Prompt and vigorous treatment is therefore indicated even in apparently minor respiratory infection in asbestos workers.

From a radiological study Sluis-Cremer (1970) concluded that the length of exposure to and the length of residence of asbestos in the lungs were important factors in determining the onset of asbestosis in South African miners of Caucasian origin, but no significant relationship has been found in our mesothelioma cases between severity of asbestosis and either of these parameters (table V).

The reports of Beattie and Knox (1961) and Nagelschmidt (1965) indicated a lack of correlation between the degree of fibrosis and the pulmonary mineral content determined from the acid-washed residue of ashed samples and the chemical estimation of silica. Nagelschmidt found only traces of asbestos or none at all in 14 out of 25 lungs, including six of 10 lungs showing severe fibrosis. The present results in severe asbestosis also show a lack of correlation between fibre content and severity or form of fibrosis, but differ sharply from these previous studies in that fibres were abundant in every case, while in the milder grades of the disease there was on average a significant increase in fibre counts with increasing fibrosis. There is no obvious explanation for the differences between the previous and the present results, and especially for Nagelschmidt's failure to find asbestos at all or only in 
traces from so many cases, but our microscopical technique may well have advantages over chemical estimation.

Electron microscope observations (Davis, 1965; Timbrell, Pooley, and Wagner, 1970) show that much of the dust found in human asbestoticlungs has a very small particle size, a large proportion of the fibres being less than $0.3 \mu \mathrm{m}$ in diameter. Such fibres would not be detected with the optical microscope used for the present studies since its theoretical resolution is $0.36 \mu \mathrm{m}$ for light of $500 \mathrm{~nm}$ wavelength. If the size distribution of the asbestos fibres in the lungs remains constant with increasing tissue asbestos content and with the passage of time, the concentration of optically invisible fibres would parallel that of the visible fibres, and the increasing asbestos counts recorded optically here could be taken to represent increasing total asbestos content of the tissues. Although the number of cases examined is small, the ultramicroscopic fibre diameter distributions in the present material suggest that the proportion of optically visible fibres does remain reasonably constant between 12 and $30 \%$ of the total, irrespective of the degree of fibrosis. An optical count could thus be held to give a reasonable indication of the total asbestos concentration.

The finding of relatively little chrysotile in electron micrographs of the present cases is in keeping with the experience of Pooley (1972) who reported a predominance of amphibole fibres in lung tissue from cases of mesothelioma. Detailed information about the exposure of our cases to asbestos is not available, but they were probably exposed to more than one type of asbestos. Timbrell (1972) demonstrated that, owing to its curled fibre configuration, chrysotile penetrated the air passages much less readily than the straight amphiboles, and this difference in deposition could explain our electron microscopic findings. It is most unlikely that chrysotile was lost during the preparation of specimens for the grids, since control specimens made without centrifugation showed a similar predominance of amphibole fibres.

The pathogenic significance of submicroscopic fibres remains uncertain. Although Holt, Mills, and Young (1964) showed that small particles within the range of light microscopy were capable of inducing fibrosis, the experimental observations of Timbrell and Skidmore (cited by Timbrell, 1972) suggested that in the production of asbestos longer fibres may be more important than short ones. The participation of submicroscopic fibres in the genesis of mesothelioma constitutes a separate problem.

Dr J. E. M. Hutchinson, of the Pneumoconiosis Medical Panel, gave invaluable assistance in collecting material, whilst Professor D. J. Newell kindly afforded statistical advice. The electron microscope was provided by the Wellcome Trust.

\section{References}

Beattie, J. (1961).The asbestosis body. In Inhaled Particles and Vapours, edited by C. N. Davies, pp. 434-441. Pergamon Press, Oxford. $\frac{O}{0}$

Beattie, J., and Knox, J. F. (1961). Studies of mineral content and is particle size distribution in the lungs of asbestos textile workers. $\mathcal{O}$ In Inhaled Particles and Vapours, edited by C. N. Davies, pp. $\omega$ 419-433. Pergamon Press, Oxford.

Collins, D. H., and Dible, J. H. (1935). The method of expressing the N silica content of the lung. J. Hyg. (Lond.), 35, 64-68.

Dacie, J. V., and Lewis, S. M. (1968). Practical Haematology, 4th ed., 음 pp. 68-69. Churchill, London.

Davies, J. M. G. (1965). Electron microscope studies of asbestosis in man and animals. Ann. N.Y. Acad. Sci., 132, 98-111.

Elder. J. L. (1967). Asbestosis in Western Australia. Med. J. Aust., 2, 579-583.

Gold, C. (1968). The quantitation of asbestos in tissue. J. clin. Path., 21, 537.

Heppleston, A. G. (1956). The pathology of honeycomb lung. Thorax, 11, 77-93

Heppleston, A. G. (1969). Pigmentation and disorders of the lung. In Pigments in Pathology, edited by M. Wolman, pp. 33-73. Academic Press, New York.

Holt, P. F., Mills, J., and Young, D. K. (1964). The early effects of chrysotile asbestos dust in the rat lung. J. Path. Bact., 87, 15-23.

International Union Against Cancer (U.I.C.C.) (1965) Report and 을 recommendations of the working group on asbestos and cancer. Ann N.Y. Acad. Sci., 132, 706-721.

Nagelschmidt, G. (1960). The relation between lung dust and lung $\overline{\bar{O}}$ pathology in pneumoconiosis. Brit. J. industr. Med., 17, 3 247-259.

Nagelschmidt, G. (1965). Some observations of the dust content and composition in lungs with asbestosis made during work on coal miners pneumoconiosis. Ann. N.Y. Acad. Sci., 132, 64-76.

Pooley, F. D. (1972). Mesothelioma in relation to exposure. Internat. Agency for Research into Cancer, Proc. working group to review the biological effects of asbestos, Lyon, in press.

Ross, H. F., King, E. J., Yoganathan, M., and Nagelschmidt, G. (1962). Inhalation experiments with coal dust containing 5 per $?$ cent, 10 per cent, 20 per cent and 40 per cent quartz: tissue reactions in the lungs of rats. Ann. occup. Hyg., 5, 149-161.

Sluis-Cremer, G. K. (1970). Asbestosis in South African asbestos 음 miners. Environ. Res., 3, 310-319.

Smith, M. J., and Naylor, B. (1972). A method for extracting ferruginous $D$ bodies from sputum and pulmonary tissue. Amer. J. clin. Path., 을. 58, 250-254. Smither, W. J. (1965). Secular changes in asbestosis in an asbestos $N$
factory. Ann. N.Y. Acad. Sci., 132, 166-181.

Timbrell, V. (1972). Inhalation and biological effects of asbestos. In $\mathrm{N}$ Assessment of Airborne Particles: Proceedings of the Third $\mathrm{N}$ Rochester International Conference on Environmental Toxicity, $\omega$ Rochester, 1970, edited by T. T. Mercer, P. E. Morrow, and $\sigma$ W. Stöber, pp. 429-445. Thomas, Springfield, Illinois.

Timbrell, V., Pooley, F., and Wagner, J. C. (1970). Characteristics of 0 respirable asbestos fibres. In Pneumoconiosis: Proceedings of the International Conference, Johannesburg, 1969, edited by $\mathcal{A}$ H. A. Shapiro, pp. 120-125. Oxford University Press, Cape Town. 